\title{
Cellulite: a cosmetic or systemic issue? Contemporary views on the etiopathogenesis of cellulite
}

\author{
Kamila Tokarska1, Sławomir Tokarski², Anna Woźniacka¹, Anna Sysa-Jędrzejowska³, Jarosław Bogaczewicz ${ }^{1}$
}

${ }^{1}$ Department of Dermatology and Venerology, Medical University of Lodz, Lodz, Poland

${ }^{2}$ Subcarpathian Centre of Lung Diseases, Rzeszow, Poland

${ }^{3}$ Department of Social Sciences, University of Social Sciences, Lodz, Poland

Adv Dermatol Allergol 2018; XXXV (5): 442-446

DOI: https://doi.org/10.5114/ada.2018.77235

\begin{abstract}
Cellulite (also known as gynoid lipodystrophy or orange peel syndrome) is one of the most common lipodystrophy syndromes, which affects millions of post-adolescent women. Cellulite is manifested by topographic disorders of subcutaneous tissue such as nodules, edema, and abnormal fibrosis. It is located mainly on the pelvic area, especially on the buttocks. Its pathogenesis is complexed and unclear. There are several theories about its pathophysiology. Hormonal disorders, endothelial dysfunction and genetic predispositions are taken under consideration.
\end{abstract}

Key words: cellulite, endothelial dysfunction, adiponectin, hormonal disorders.

\section{Introduction}

Cellulite (gynoid lipodystrophy - GLD), also known as "orange peel" or cottage cheese-like dimpling of the skin, is considered as a paraphysiological, cosmetically unacceptable problem. It affects millions of women but fewer men [1]. It constitutes an enormous challenge for the contemporary cosmetic surgery. Cellulite treatment is tedious and expensive, and its effectiveness is doubtful. Morphologically, cellulite is regarded as lipodystrophy, or rather as the degeneration of adipose tissue. It should not be confused with "cellulitis", a term used in dermatology to describe inflammation of the subcutaneous tissue. Changes occurring in the course of cellulite formation are fibrosis and sclerosis, which manifest clinically as a wavy course of the skin surface and multiple nodules, which are palpable. In cases of significant advancement of changes, nodules and sclerotic lesions are accompanied by soreness, dryness and thinning of the skin covering the changed area. Most often, this problem affects the subcutaneous tissue around the thighs, buttocks and hips, the areas where adipose tissue is deposited in the largest amounts in women. Cellulite formation accelerates during adolescence [2], pregnancy or in women around the menopausal age. It is estimated that the disease may affect up to $85 \%$ of women over 20 years of age [3].
The current classification of cellulite includes a fourstage scale referring to the clinical grade of the disease [4] (Table 1).

For many years, GLD was considered only as an esthetic problem. According to the contemporary literature, its etiology is heterogeneous. It is now believed that a positive correlation exists between the clinical stage of cellulite and a predisposition for systemic diseases. Recent studies of the pathogenesis of cellulite have prompted a search for its underlying causes in blood vessels and the metabolic processes of the subcutaneous tissue under the influence of chronic ischemia [3]. The main function of adipocytes in the human body is to store and metabolize fatty acids. Attention has been paid to their complex endocrine activity. Dysfunction of adipocytes may not only lead to changes in skin topography, resulting in an unwanted visual effect, but may also affect the metabolism $[5,6]$.

\section{Etiology}

The etiopathogenesis of cellulite is multifactorial and unclear, but it is known to incorporate environmental, hormonal and genetic factors. The severity of cellulite is known to be similar in related women. In addition, incidence and severity are influenced by sex, being more common in women than men, race, being more common in Caucasians, and biological type, being found on the

Address for correspondence: Kamila Tokarska MD, Department of Dermatology and Venerology, Medical University of Lodz, Pl. Hallera 1, 90-647 Lodz, Poland, phone: +48 500144 909, e-mail: kamka1990@o2.pl

Received: 20.04.2017, accepted: 27.06.2017. 
Table 1. Classification of cellulite

There is no alteration of the skin topography. The skin of the affected area is smooth while standing or lying, but the alterations of the skin surface can be seen by pinching the skin or with muscle contraction

The skin around the affected area is smooth while standing or lying. Changes can be seen while pinching the skin

The skin is smooth while lying, but alternations are observed while standing

The alterations described in stage III are present together with raised areas and nodules. The changes are accompanied by soreness and pain

hips and thighs of Latin American women but not on the abdomen of European women [3, 7-9].

There is no doubt that improper lifestyle is an important accelerator of the syndrome. Excessive intake of food products rich in fats, with a high salt and preservative content has been associated with the development of various metabolic disorders including hyperinsulinemia, a condition which can increase lipodystrophy. A sedentary lifestyle plays a similar role [3, 9, 10]. Lack of physical activity increases the severity of cellulite, by weakening the muscle layer of the blood vessels and causing local hemostasis. This condition leads to secondary hypoxia and ischemia of the adipose tissue. Alcohol consumption stimulates lipogenesis and causes body dehydration, resulting in the excessive and improper storage of fat. Smoking results in significantly greater amounts of free radicals in the body, and the contraction of small blood vessels responsible for local micro-circulatory impairments. This can contribute to the development of GLD, resulting in its clinical progression [11].

Female sex hormones play a significant role in the development of lipodystrophy $[11,12]$. The first symptoms of fatty tissue topography disorders appear in puberty. The exacerbation and progression of skin lesions correlates with pregnancy-related hyperestrogenism, or the use of birth control pills or hormone replacement therapy in postmenopausal women. Some authors specify estrogen as the main factor causing the occurrence of GLD [11]. Excessive quantities of estrogen may provoke cardiovascular problems. Excessive relaxation of the veins is observed, causing blood stasis, resulting in swelling, ischemia and hypoxia in the subcutaneous tissue [3,9]. The influence of estrogen on the blood vessel wall is also manifested by increased wall permeability, which may lead to the swelling of the surrounding tissues. This swelling places pressure on small veins and arterioles, leading to the abnormal blood flow within the skin and fatty tissue. The process is exacerbated by a combination of a lack of progesterone and hyperestrogenism, resulting in abnormal metabolism and impaired adipocyte function. These phenomena exacerbate fibrosis and the formation of nodules in the subcutaneous tissue, which inevitably lead to the progression of cellulite $[3,9,11]$.

The tissues undergoing lipodystrophy present histopathological changes. In patients with cellulite, microscope observation reveals swelling of the subcutaneous tissue, decay and change of the adipocyte structure, enlargement and thickening of the vascular endothelium, hyperplasia and hypertrophy of the reticular fibers, as well as subcutaneous microangiopathy. In later stages, extensive vascular disorders, atrophic-dystrophic skin anomalies and appendage disturbances are noticeable, as well as the blurring of the border between the skin and underlying tissue $[13,14]$. Comorbidity of microcirculation disorders within the subcutaneous tissue, associated with the endocrine function of adipocytes and endothelial cells may increase the risk of cellulite. Adipocyte dysfunction results in the failure of endocrine function. In this case, GLD should be considered a systemic problem rather than simply a cosmetic defect $[1,9,15]$.

\section{Adipose tissue as an endocrine organ}

The structural unit of adipose tissue is an adipocyte. These cells are dispersed within a scaffold consisting of collagen fibers. In addition to adipocytes, the adipose tissue consists of preadipocytes, fibroblasts, leukocytes, macrophages, endothelial cells and myocytes. The presence of these cells suggests that body fat performs a complex and heterogeneous function beyond that of lipid storage. Cellulite should not be confused with obesity, in which a gain in adipose tissue mass results from an increase in adipocyte cell size and number.

The primary function of the adipocyte is associated with the metabolism of fatty acids. They also have a lot of endocrine functions [16]. The substances secreted by these cells, known as adipocytokines, include leptin, adiponectin, angiotensinogen, resistin, tumor necrosis factor $\alpha$ (TNF- $\alpha)$ receptor activating peroxisome proliferation $\gamma($ PPAR- $\gamma$ ), interleukin-6 (IL-6), insulin-like growth factor-1 (IGF-1), lipoprotein lipase (LPL), and adipsin (plasminogen activator inhibitor 1 - PAI-1) [5, 17]. The secretion of fatty acids, cytokines, and various hormones with profound paracrine and/or endocrine effects influences metabolism, endothelial function, inflammation, and extracellular matrix deposition. Emanuele et al. revealed the reduced expression of adiponectin mRNA in areas with cellulite compared with those without. However, plasma adiponectin levels did not differ between women with and without cellulite, what suggests that this molecule may act as a local paracrine factor that influences the appearance of the skin [18]. 
Other studies support the thesis that endocrine function of subcutaneous adipose tissue may functionally affect the subcutaneous vascular and lymphatic circulation and possibly influence the formation of cellulite [19].

Adipocytes are equipped with a number of specialized receptors enabling them to interact with the endocrine system $[6,16,20]$. Disorders of the adipocyte endocrine function correlate with the current state of the metabolism. Endocrine system failure is observed both in the case of excess adipose tissue (insulin resistance, diabetes), and its deficiency (malnutrition) [6, 20]. Impaired secretion and production of adipocytokines results in the disruption of homeostasis. Excess body fat is associated with insulin resistance, hypertension and an increased risk of atherosclerosis. These factors directly affect the vascular dysfunction, not only regarding cardiovascular events. Adipocytes become hypertrophic when adipose tissue is in excess, and progressive reduction of microcirculation is observed in the local area as the individual cells mutually constrict each other. It is believed that the coexistence of the aforementioned factors can play a role in the pathogenesis of lipodystrophy [16, 21].

\section{Vasculitis and endothelial dysfunction in the pathogenesis of cellulite}

Contemporary literature attributes a key role in the pathogenesis of many diseases to the dysfunction of the vascular endothelium [22]. This single layer of cells lining the inside walls of blood vessels is considered to be a separate organ because of its endocrinal, vasodilatory and vasoconstrictive attributes. Endothelial dysfunction has long been recognized as an independent risk factor for the cardiovascular disease, cancer and type II diabetes. Endothelial damage is regarded as a pathomechanism in the case of insulin resistance, in which damage results in the production of reactive oxygen species and the excessive glycosylation of proteins, thus reducing the availability of nitric oxide, and increasing the production of growth factors and pro-inflammatory cytokines [22]. A similar situation has been speculated in the case of cellulite.

A local inflammatory process dependent on macrophages and Th1 cells can influence the endothelial dysfunction in obese people experiencing GLD. In obese people, increased recruitment of $\mathrm{M} 1$ macrophages has been demonstrated [23]. This type of macrophages, together with mast cells, is responsible for the development of inflammation and the production of pro-inflammatory cytokines (IL-6, IL-12, TNF- $\alpha$ ). A large number of them are present in the adipose tissue of obese people. Elevated production of pro-inflammatory cytokines such as TNF- $\alpha$ and interleukin- 6 is associated indirectly with the coexistence of insulin resistance [23]. It has also been demonstrated that a high level of IL-6 is an independent risk factor for cardiovascular events [8]. A correlation between obesity, insulin resistance, local inflammation and endothelial dysfunction is possible. As these factors have been found to co-occur in cellulite, it is possible that they share a similar pathology with that of the vascular endothelium [24, 25].

\section{Hypoxia inducible factor 1 protein}

Hypoxia inducible factor 1 (HIF-1) is a heterodimeric (A/B) transcription factor, of which the $\alpha$ subunit (HIF1A) is directly regulated by oxygen tension [26]. It is sensitive to the concentration of oxygen in the cellular environment. The HIF occurs in all tissues of the human body. It regulates gene expression in response to hypoxia, resulting in counteracting the harmful effects associated with lack of oxygen. During hypoxia, the expression of the HIF-1 gene stimulates the production of the GLUT 1 protein, erythropoietin, transferrin and vascular endothelial growth factor (VEGF), which enable the cells to prepare for hypoxia [27]. This results in the stabilization of HIF1A subunits and the activation of hypoxia-inducible gene expression. An increased expression of HIF-dependent protein- 1 has been observed in many malignant tumors [23]. Its expression is associated with a rapid and uncontrolled proliferation of cancer cells and insufficient neoangiogenesis [27].

Adipose tissue expansion in response to increased caloric intake is regarded as a potent stimulus to HIF1 gene expression, which stimulates a fibrogenic response typical for cellulite. Ischemia and hypoxia also play a role in cellulite. Microcirculation disorders, local inflammation, endothelial dysfunction and fibrosis of subcutaneous tissue all occur as responses to chronic hypoxia. In fat tissue, HIF-1 expression has been found to activate fibrosis and local inflammation. T-allele of polymorphism 11549465 for HIF1A reduces the activity of the HIF-1A factor in patients, and one study found that women presenting this particular polymorphism did not develop cellulite, or if they did, it was at a low level [22]. This relationship illustrates the connection between GLD and HIF1 factors, and represents another link between local micro-circulation disorders and the development of lipodystrophy.

\section{Adiponectin/leptin}

Adiponectin is a peptide that belongs to a group of adipocytokines, molecules secreted by adipocytes, and serves a vasoprotective and antiatherogenic agent. In addition, adiponectin protects the vascular endothelium and facilitates the proper metabolism of glucose and lipids. Reduced concentrations of this peptide are observed in obesity, diabetes, hypertension and coronary heart disease, while high concentrations have been documented in cases of longevity. In addition, a close relationship has been noted between low concentrations of adiponectin, 
insulin resistance and the risk of developing type 2 diabetes [28]. Adiponectin is known to not only have strong antiatherogenic properties, but also to act as a vasodilatory and anti-inflammatory factor. Low levels of this protein correlate with impaired vasodilation, thus impeding microcirculation [28-30]. These findings imply a probable link between low concentrations of adiponectin and the development of cellulite.

Leptin is also synthesized by adipocytes. The amount of leptin correlates with the size of the adipocyte and with the state of the metabolic system. Its synthesis and secretion are governed by hormonal processes and anthropometric indicators such as BMI or type of diet [31, 32]. This adipocytokine also serves to control the satiety center by activating combinations of their respective receptors. Leptin levels are positively correlated with the obesity, insulin resistance and increased risk of cardiovascular events [33]. Several studies have confirmed the relationship between hyperleptinemia and endothelial dysfunction. Elevated leptin levels are closely related to local reductions in nitric oxide levels and abnormal local angiogenesis. Hyperleptinemia has been suggested to play a role in vascular endothelial cell migration, the process co-responsible for neoangiogenesis in diabetes and development of cardiovascular complications [33]. Adiponectin and leptin work antagonistically, and their concentrations reflect the present metabolic state. The manifold effect of these proteins on the endothelium and the micro-vascular system of adipose tissue may indicate that they influence the development of cellulite.

\section{Conclusions}

The pathogenesis of cellulite is heterogeneous and unclear. Most of the current data indicate that endothelial dysfunction and micro-circulation disorders play important roles in the etiology of this phenomenon. The presence of disorders in the vessel and the endocrine system combined with a genetic predisposition may aggravate the process. The involvement of many complex mechanisms of the body implies that cellulite is not only a cosmetic issue, but also develops as a result of interdisciplinary homeostatic disorders.

\section{Acknowledgments}

Manuscript was founded by Medical University of Lodz, from statutory funds (503/1-152-01/503-11-002).

\section{Conflict of interest}

The authors declare no conflict of interest.

\section{References}

1. Załęska-Żyłka I. Cellulit jako problem medyczny. Probl Hig Epidemiol 2008; 89: 487-91.
2. Rossi A, Vergnanini A. Cellulite: a review. J Eur Acad Dermatol Venereol 2000; 14: 251-62.

3. Gałązka M, Galęba A, Nurein H. Cellulit jako problem medyczny i estetyczny - etiopatogeneza, objawy, diagnostyka i leczenie. Hygeia Public Health 2014; 49: 425-30.

4. Adamski Z. Kaszuba A. Dermatologia dla kosmetologów. PZWL, Warsaw 2010.

5. Ahima R, Flier J. Adipose tissue as an endocrine organ. Trends Endocrinol Metab 2000; 11: 327-32.

6. Faraj M, Lu H, Cianflone K. Diabetes, lipids, and adipocyte secretagogues. Biochem Cell Biol 2004; 82: 170-90.

7. Ignaciuk A. Diagnostyka kliniczna - cellulite. Mag Med Estet 2004; 1: 15-7.

8. Lupi O, Semenovitch I, Treu C, et al. Evaluation of the effects of caffeine in the microcirculation and edema on thighs and buttocks using the orthogonal polarization spectral imaging and clinical parameters. J Cosmet Dermatol 2007; 6: 102-7.

9. Janda K, Tomikowska A. Cellulit - przyczyny, profilaktyka, leczenie. An Acad Med Stetinensis 2014; 60: 29-38.

10. Smalls L, Hicks M, Passeretti D, et al. Effect of weight loss on cellulite: gynoid lypodystrophy. Reconstr Surg 2006; 118: 510-6.

11. Drąg J, Goździalska A, Jaśkiewicz J. Udział hormonów płciowych w patofizjologii cellulitu. Wydział Zdrowia i Nauk Medycznych, Krakowska Akademia im. Andrzeja Frycza Modrzewskiego, Krakow 2013.

12. Frandofert M, Goździalska A, Jaśkiewicz J. Lipodystrofia jako problem czasów wspótczesnych. Wydział Zdrowia i Nauk Medycznych, Krakowska Akademia im. Andrzeja Frycza Modrzewskiego, Krakow 2013.

13. Rossi A, Vergnanini A. Cellulit - praca przeglądowa. Derm Estet 2002; 1: 4-10.

14. Pieniążkiewicz J. Cellulit - profilaktyka i zwalczanie. Współpraca kosmetologa z lekarzami różnych specjalizacji. Raabe, Warsaw 2006.

15. Terranova F, Berardesca E, Maibach H. Cellulite: nature and aetiopathogenesis. Int J Cosmet Sci 2006; 28: 157-67.

16. Skowrońska B, Fichna M, Fichna P. Rola tkanki tłuszczowej w układzie dokrewnym. Endokrynol Otył Zab Przem Mat 2005; 3: 21-9.

17. Poulos S, Hausman D, Hausman G. The development and endocrine functions of adipose tissue. Mol Cell Endocrinol 2010; 323: 20-34.

18. Emanuele E, Minoretti P, Altabas K, et al. Adiponectin expression in subcutaneous adipose tissue is reduced in women with cellulite. Int I Dermatol 2011; 50: 412-6.

19. Prins JB. Adipose tissue as an endocrine organ. Best Pract Res Clin Endocrinol Metab 2002; 16: 639-51.

20. Kershaw E, Flier J. Adipose tissue as an endocrine organ. J Clin Endocrinol Metab 2004; 89: 2548-56.

21. Kowalska K. Naturalne związki zaangażowane w kontrolę masy tkanki tłuszczowej w badaniach in vitro. Postepy Hig Med Dosw 2011; 65: 515-23.

22. Tomczyk M, Nowak W, Jaźwa A. Śródbłonek w fizjologii i patogenezie chorób. Postep Biochem 2013; 4: 357-64.

23. Lumeng C, Bodzin J, Saltiel A. Obesity induces a phenotypic switch in adipose tissue macrophage polarization. J Clin Invest 2007; 117: 175-84.

24. Łuczak M, Drzewiecka H, Jagodziński P. Czynnik indukowany HIF. Nowiny Lekarskie 2009; 78: 237-48.

25. Biesaga B. Regulacja ekspresji białka HIF 1 jako nowa strategia celowanej terapii nowotworów złośliwych. Nowotw J Oncol 2008; 3: 255-9. 
26. Emanuele E, Bertona M, Geroldi D. A multilocus candidate approach identifies ACE and HIF1A as susceptibility genes for cellulite. J Eur Acad Dermatol Venereol 2010; 24: 930-5.

27. Baranowska B, Bik W. Fizjologiczna rola adiponektyny. Postep Nauk Med 2010; 6: 503-8.

28. Ewart A, Perry C, Connell J, et al. The role of insulin and the adipocytokines in regulation of vascular endothelial function. Clin Sci 2004; 107: 519-32.

29. Tan K, Xu A, Chow W. Hypoadiponectinaemia is associated with impaired endothelium-dependant vasodilatation. J Clin Endocrinol Metab 2004; 89: 765-9.

30. Shimabukuro M, Higa N, Asahi T. Hypoadiponectinaemia is closely linked to endothelial dysfunction in man. J Clin Endocrinol Metab 2003; 88: 3236-40.

31. Jasińska A, Pietruczuk M. Adipocytokines - proteins of multidirectional function. J Labor Diagn 2010; 3: 331-8.

32. Guzik T, Mangalat D, Korbut R. Adipocytokines - novel link between inflammation and vascular function? J Physiol Pharmacol 2006; 57: 5028-65.

33. Karbowska J, Kochan Z. Leptyna jako hormon łączący otyłość z dysfunkcją mięśnia sercowego. Postep Hig Med Dosw 2012; 66: 267-74. 